\title{
Economic and Energy Factors on the Formation of USA Foreign Policy
}

\author{
A. Kapyshev ${ }^{1}$, S. Kapysheva
}

\begin{abstract}
:
This paper presents the impact of foreign economic and energy factors on formation of the foreign policy strategy of the USA.

In the author's opinion, the contemporary energy policy is one of the main issues of the US foreign policy in the international area, as it is aimed at meeting the increasing demands of the USA for energy resources and maintaining the world-leading status of American economy.
\end{abstract}

As a result, the author comes to conclusion that foreign economic activity and energy factor in the US foreign policy actively help to introduce own TNC into different countries, which, in their turn, solve not only their corporate tasks, but also contribute to the achievement of the US foreign policy goals.

Keywords: American economy, conflict of interests, energy resources and security, US foreign policy.

\footnotetext{
${ }^{1}$ Associate Professor, Head of International Relations and History Department of Kokshetau University named after Abai Myrzakhmetov, Kokshetau, e-mail: universityadmin@pochtaweb.ru
} 


\section{Introduction}

At the end of the $20^{\text {th }}$ century, a certain shift in priorities took place in the US foreign policy which was conditioned by drastic changes in geopolitical alignment of forces on our planet, followed the end of Cold War. The USA began to pay less attention to the nuclear missile factor in its national security protection and greatly emphasized the guarantee of unimpeded access to those world resources which represent the strategically important interest from the perspective of assurance of the unimpeded functioning of American economy (Kuranov, 2010). Among them, nonrenewable fuel and energy resources, namely oil and gas, are of the greatest significance.

The US is distinct for the least intervention of the state into the oil sector activities. Using a metaphor, it can be said that the USA are the "golden standard" of market relations generally and oil and oil product market, particularly. As a matter of fact, the figures characterizing the oil and oil product market are impressive. The country consumes about 20 million barrels ( $\mathrm{mln}$. b/d) of oil products a day, the half of which are imported in the form of crude oil $(8.6 \mathrm{mln}$. b/d) and in the form of oil products ( $2.2 \mathrm{mln} . \mathrm{b} / \mathrm{d})$. The general production capacity of 174 OPPs (oil-processing plants) existing in the country is $16.7 \mathrm{mln}$. b/d. Presently, $86 \%$ of the general production capacity is used, and that means that about $14-15 \mathrm{mln}$. b/d are supplied to OPPs by local suppliers or from abroad without any interference of the state.

Presently, the foreign economic policy holds one of the central positions in the system of foreign economic actions of the USA in the world arena, and that objectively implicates new forms of complications in its relations with Russia (in the regions of Caucasus and Central Asia). The increase of the role of foreign energy policy is connected with the fact that the USA is the largest consumer of energy resources, and after the breakdown of USSR it has become their largest producer. In the second half of $1990^{\text {th }}$, the level of consumption of primary energy resources in the USA had exceeded 2,100 mln. t. of oil equivalent (t.o.e.), which made approximately $24 \%$ of the world level (Karpov, 2008). At the same time, the level of internal production of primary energy resources reached 1650-1700 t.o.e., or about $19 \%$ of that of the world. The power consumption of the USA economy amounts to 0.42 t.o.e. per $\$ 100$ of GDP (by the end of the century, the US GDP reached $\$ 9$ bln. in the current prices). In contrast to the majority of other industrially developed countries, the USA own large reserves of energy raw materials $(2.9 \%$ of world oil reserves, $3.3 \%$ of gas, and $23 \%$ of coal).

However these are not enough for a stable development of the American economy and assurance of high level of consumption by American population in a long-term perspective (Hamilton, 2000). The United States import a considerable part of consumed oil. At that, the share of import oil in its general consumption increased from $35 \%$ in 1973 to $52 \%$ in 1998 and can reach $66 \%$ by 2010 . At the same time, 
the United States is an exporter of a considerable part of coal, as well as large quantities of energy equipment and services.

The major part of American companies involved in energy supply of the USA are transnational corporations (TNCs). At the end of $1990^{\text {th }}$, their profits exceeded $\$ 600$ bln, or approximately $7 \%$ of the state GDP. These companies continue to play a leading role in the world's energy supply. In 1997-1998, the share of oil and gas produced by TNCs in the US and abroad amounted to over $13 \%$ and approximately $22 \%$ respectively of the world-wide level. The total volume of oil and gas produced at foreign deposits is commensurable with the volume of domestic production. American TNCs have the access to major oil and gas deposits of the world. The shares of the world's reserves controlled by them are $3.3 \%$ of oil and $3.7 \%$ of gas. Moreover, a considerable part of these reserves was concentrated outside the USA. American companies, in terms of volumes of production and possession of hydrocarbon resources, rank high in the group of 200 major oil and gas companies of the world. In the mid- $1990^{\text {th }}$, this group, in which the state-owned companies of the leading oil production countries hold the first place, included "Exxon", "Mobil", "Texaco", "Chevron" (Hamilton, 2000).

The American companies aspire to expand the access to oil and gas deposits in the CIS countries which can considerably strengthen their leading positions among other west countries in terms of resource-raw material provision index. It is necessary to mark that the foreign policy of the USA is formed to a considerable extent under the influence of energy companies which aspire to keep the leading positions in the world power industry. Promoting the interests of American companies, the US diplomacy frequently uses them for strengthening its foreign policy positions in strategically important regions of the world.

\section{American national interests and important regions: The Caspian sea and the Middle East}

The key priorities of the US foreign energy policy are in many respects determined by the fact that they are the leader in the field of development and coordination of the general energy policy of the industrially developed countries. Concerning the formation of the national security strategy, which is annually updated and presented by the American president in the USA Congress, as early as in 1994 it was stated that the protection of the US energy security rank among the key priorities of the country's foreign policy: "The interruptions in oil supplies can have a substantial impact on the US economy. Thus, appropriate foreign political measures can limit the scales of possible energy crisis. In spite of the measures for conservation of own oil deposits, the USA is highly interested in an unimpeded access to this important raw material abroad".

In the report titled American National Interests published in July 1996 by the specially formed Commission for American National Interests, among a number of 
American vitally important interests, which are understood as "absolutely critical conditions of protection and strengthening the wealth of Americans as free and safe nation", are prevention of the collapse of major global systems - trade, financial markets, energy supplies and environment.

According to the survey of political elite conducted in the mid-1990"th, "the provision of adequate sources of energy" holds the second place after "prevention of nuclear weapon proliferation" in the hierarchy of foreign policy objectives. The goals of the US foreign energy policy arise from the National Energy Strategy of 1991 which was reviewed in 1998. They are aimed at meeting of the growing demands of the USA in energy resources, on maintaining the world's leading position of the American economy, at the reduction of the dependence of the US, its friends and allies from the potentially unreliable suppliers of energy resources, and at performance the obligations related to environmental protection.

As the key domain of activities within the foreign energy policy, the Strategy declares the improvement of the US energy security, along with strengthening and enhancing the global energy security system, development of world energy markets, as well as addressing the environmental issues of the world energy. First of all, the question is prevention of the interruption in energy resource supply and sharp fluctuations of world prices for energy products, and conservation of its own reserve of energy sources, namely oil. The Strategy pays great attention to the study and control of the state of world market of energy resources, services, technologies and investments into the fuel and energy branches.

The relations with countries possessing large reserves of energy resources, first of all, with the countries of Persian Gulf and Latin America, are of priority for the USA. A great attention is paid to the development of development of energy cooperation with Russia and other countries of the Caspian region. Concerning the latter ones, a special emphasis is made on the assistance to market transformations which also strengthen the positions of American companies in these countries. The Caspian region, along with the Persian Gulf, is officially treated by the US Department of State as a region of "vitally important interests" of America affecting the national security of the country. It is motivated not only by the aspiration to assure own energy security; there is an obvious intention of the USA to control, at the same time, the access to the Caspian and the Persian hydrocarbons and ways of their transportation with the purpose of strengthening its geopolitical and economic standing in the world after the end of the Cold War and the breakdown of USSR, and also its influence the situation at the global hydrocarbon market (Stepanova, 2002).

It must be noted that there is a close connection between the goals and priorities of American foreign energy policy and foreign policy goals. For example, the American diplomacy, promoting the strengthening of the positions of companies in the Caspian region, thus contributes to the increase of the US political influence in 
this region. The cases of indirect usage of American companies as an instrument of foreign policy are not uncommon. For achievement of the key goals of its foreign energy policy, the USA aspires to diversify its reliable supplies. A special role in this aspect, along with bilateral diplomacy, is assigned to the multilateral cooperation within international organizations, on regional and global levels.

On the global level, the American energy diplomacy pays great attention to the International Energy Agency (IEA) established in 1974 on the initiative of the then US Secretary of State H. Kissinger. It plays an important role in the improvement of the energy security of America and other industrially developed countries. It should be mentioned that the USA could preserve the significance of American oil companies in the system of energy security of the IEA member states. Owing to the principle of "weighed" voices, the USA plays a key role in the agency, which they often use for achievement of the goals of own foreign energy policy (Bialos, 1987).

In particular, the American diplomacy raises the issue of holding conferences and studies on the problems of production and transportation of the Caspian hydrocarbons under the aegis of IEA. It should be mentioned that except for IEA, the global aspects of energy problematic were often discussed, on the US initiative, within the frameworks of annually meetings of G7. On the initiative of the American diplomacy, IEA increasingly pays attention to the global problems of the energy industry, including world markets and ecology (Kuranov, 2010).

The USA maintains contacts with major international organizations uniting the oil production countries, Organization of the Petroleum Exporting Countries (OPEC) and the Group of Independent Petroleum Exporters (GIPE). In the relations with OPEC, the opportunities of annual global energy conferences and other forums are used most frequently. However, the preference is given to usage of such oil producing countries which are close to the USA, as Saudi Arabia and Kuwait, for influencing this organization in the field of pricing policy. Moreover, often IEA serves as means of influence over OPEC positions. A range of American oil production states cooperate with independent petroleum exporters within the group of independent petroleum exporter countries.

Within the framework of regional directions of the US foreign energy policy, the priority is given to cooperation within the North-American Free Trade Area (NAFTA) created in 1994, which members are the USA, Canada and Mexico. In the agreement on NAFTA establishment, there is special "Energy" section which stipulates the principles of relations in the field of energy, including trade and economic and financial and investment issues, as well as in the field of energy security. The main interest of the USA in energy cooperation within NAFTA is the formation of the internal North-American energy market, where the leading part is played by the US companies. 
In Latin America, energy resources of the USA are connected, in the first instance, with assuring reliable supplies of energy resources, as well as with improvement of the positions of American companies in the region. The cooperation with the USA is developed on bilateral basis and within the framework of the OAS, uniting the countries of North and Latin America. High hopes are put on the development of cooperation with basic economic groups of the countries of Latin-American region within NAFTA (Victor et al., 2014).

As the processes of rapprochement with APR counties develop, many of them enter into different organizations of sub-regional economic integration (ASEAN, NAFTA), the USA aspire to play a dominating role in the energy policy of these states. In this connection, the American diplomacy attaches great importance to the active participation in the work of energy group within the Forum of Asia-Pacific Economic Cooperation created at the intergovernmental level. On the initiative of the USA, the possibility of creation of a constant body of regional energy cooperation similar to IEA type, and also the formation of APEC system of energy security, are studied.

On a bilateral basis, the USA actively develops its relations with Japan, China, South Korea and Indonesia. In relations with main oil production countries of North Africa, Near and Middle East, the USA pursues a differentiated policy. The main partners of the USA are Saudi Arabia, Kuwait and UAE. Recently, the relations with Algeria became more active. In relation with "disgraced" states (Libya, Iraq, Iran), a strict policy of sanctions, including with the use of the US opportunities in the UNO, is pursued.

The USA took active part in the development of the European Energy Charter which was signed by it in 1991. As to the Energy Charter Treaty, at that time the USA actively participated in its development, but didn't sign it after finishing the work on it in 1994, as a result of a range of reasons, among which it is possible to distinguish a formal preservation of the Jackson-Vanik amendment providing for the possibility of application of discrimination limitations in foreign economic relations with Russia.

Russia and other CIS countries hold an important place in the US foreign energy policy. In Russian-American relations, the energy factor is present, someway or other, at all levels, and is put on the agenda of many talks. Herewith, the main interest of the USA lies in granting the access to Russian oil and gas deposits to American companies on acceptable conditions and with appropriate protection of investments. The issues of participation of American companies in specific projects, of transportation of the Caspian oil and of the Russian position in determination of the legal status and regime of Caspian Sea, are raised most frequently. Moreover, the big interest is paid to modernization of fuel and energy industry of Russia, including electric power, where peculiar attention is paid to nuclear safety of the Russian APPs. In particular, through and at the expense of the US Department of State, a 
comprehensive multi-variant study of the prospects of electric energy development of Russia was arranged.

The Caspian issue is a priority in the American foreign policy. The Caspian region, which includes, as regarded by the USA, not only the countries surrounding the Caspian sea, but Georgia and Armenia as well, and also Uzbekistan and other Central Asian republics, attracted the attention of the USA immediately after disintegration of the USSR, because in the conditions of appearance of independent states, its geopolitical significance at the intercrossing of communication lines between Europe, Asia and Persian Gulf area, has increased.

This circumstance influenced the USA policy in respect of resolving the conflict situations in the region (Georgian-Abkhazian, Georgian-Ossetian, ArmenianAzerbaijani and other conflicts, including military actions of Russian in Chechnya in 1999-2000), and also the increase of its influence in the new states. In the capitals of new independent states, embassies were opened with numerous, and, at first sight, inadequate to the scales of these countries, staffs of diplomatic workers. Moreover, these countries received considerable financial aid through USIA, USAID, and other governmental institutions.

Additional interest of the USA to the region was generated by the data of geological studies conducted in the Soviet time and complemented by western companies, concerning large oil and gas deposits at the Caspian seabed and in the adjacent new independent countries. According to the estimations of the Department of State presented in 1997 in the US Congress, general oil reserves (proved and recoverable) amounted to more than $20 \mathrm{bln}$. t, which puts the region at the second place in the world after the Persian Gulf. Moreover, gas deposits are significant.

However a lot of opinions arose about substantial overvaluation in the Department of State's "geological" estimation, which obviously was made intentionally with the purpose to attract as many companies as possible to the development of the Caspian region. The Caspian hydrocarbons are considered in the USA an important factor, capable to influence the support of a balanced development of the world's oil market in the first half of the $21^{\text {st }}$ century, as well as to lead to certain reduction of the USA's and other industrially developed countries' dependence on the oil import from the countries of Persian Gulf, where the political instability is predicted to be continued. The anticipated reserves in the Caspian Sea are large enough to provide for long-term supplies to the USA and other countries. Although the Caspian resources don't change the dominant position of the Near East, they are able to impose a restraining effect on the rise of prices and stabilization of the situation on the world's energy markets.

One of the strategic goals of in the US energy policy is weakening of the unacceptable tendency of domination of the Near East countries in the world export of oil and diversification of the supplies from other regions, including the Caspian 
region, which was officially declared as a part of the area of strategic interests of the USA along with the Persian Gulf. It is important to note that the Caspian problems in the USA are solved at the level of the President, and for interdepartmental coordination, a special agency headed by the NSC was created. At present, the main coordinator of the Caspian direction in the American foreign policy is J-Wolf, a special representative for energy diplomacy in the Caspian region of the President and the US Secretary of State (Bialos, 1989).

Geopolitical objectives of the USA lie in the fact that supporting the development of oil and gas industry in the Central Asia countries and Azerbaijan promotes the strengthening of their independence and political rapprochement to the West. The American diplomacy actively contributes to the introduction of the USA companies in the countries of the region. In its turn, the American companies don't just perform their own corporate tasks, but also contribute to the achievement of the US foreign policy goals.

Presently, in the Caspian direction of the USA policy, connected with energy factors, the biggest attention is paid to four problems: the legal status and the regime of Caspian Sea, ways of transportation of Caspian hydrocarbons to the world markets, investments to Caspian oil and gas projects, and assuring the safety of transportation of Caspian hydrocarbons. Addressing each of these problems with due care, the American diplomacy pays great attention to the issues of political and economic stability in the countries of the region, as well as of adjacent regions.

The USA's official position in respect of the legal status and the regime of the Caspian Sea (LSRCS) is reduced to that this problem must be regulated by only five Caspian states (Russia, Azerbaijan, Kazakhstan, Turkmenistan, and Iran). However, at the same time, it is emphasized that the USA, being the country with large investment interests in the region is interested in the LSRCS to provide for a favorable climate for American investors. Thus, the USA does not intend to support such LSRCS solution which would lead to the delay in implementation of large projects or to limit the participation of American companies in these projects.

The USA is interested in stepping up the division of Caspian Sea by national sectors in order that each of the Caspian countries would have property rights, on the basis of which foreign companies could sign relevant contracts and begin to develop hydrocarbons. This position of the USA was brought to the notice of Kazakhstan and Azerbaijani governments, which, on the assumption of coincidence of their national and American interests, in general, promptly follow American instructions at the talks related to the development of a convention on legal status of the Caspian Sea (Geri, 2001).

With the aim of solving the LSRCS problem, to its own benefit, the USA takes measures within its relations with the Caspian countries (Kazakhstan and Azerbaijan), and also with industrially developed countries, aspiring to 
internationalize Caspian problems. It is important to note that some American companies, which primarily had a dominating role in the Caspian projects, assigned their shares to companies from other industrially developed countries, generally to G7 countries, which is in line with the Department of State's policy of internationalization of Caspian problems. These companies pay great attention to the development of LSRCS and its formalization in appropriate international legal form.

Taking into account that without arrangement of a reliable transportation of the Caspian hydrocarbons to the world market the development of the energy resources of the Caspian Sea almost has no sense, the USA diplomacy pays great attention to the issue of pipelines. In this connection it is appropriate to state that the USA is interested the multi-variant nature of transportation projects in order to avoid monopoly of one country (Turkey or Russia) on the routes of pipelines. Herewith, it is necessary to emphasize that the American position, at first sight, accommodates the interests of Russia in the part that Tengise and Caspian oil from other Azerbaijan deposits would be pumped through the Russian territory.

In particular, the American government supports the project of Caspian Pipeline Consortium (CPC). At the same time, the USA gives unprecedented diplomatic support to the "Baku-Jaikhan" oil transportation project through the territory of Turkey, in spite of its economic unattractiveness for transnational companies participating in the development of Caspian deposits, which do demonstrate much interest in implementation of the project.

The American diplomacy actively lobbies the project of construction of a transCaspian pipeline for transportation of Turkmen gas through the territory of Azerbaijan and Georgia to Turkey. The USA aspires to interlink the two projects, as they are important for American foreign political strategy, first of all, from the perspective of their geopolitical interests in the region. At the end of November 1998, in the course of OSCE summit in Istanbul under patronage of the USA president B. Clinton, a number of Caspian states, as well as Turkey and Georgia, signed a package of political agreements about construction of "Baku-Jaikhan" pipeline and trans-Caspian pipeline.

At the same time, quite active attempts of American official representatives to use political and other levers of pressure with the purpose to discredit Russian-Turkish "Blue Flow" project, providing for construction of pipeline along the bottom of Black Sea for export of Russian gas to Turkey and, probably, to other Mediterranean countries. In connection with that, the Russian MFA, in August 1999, brought such actions to the notice of the USA Embassy representative (Cox \& Stokes, 2008).

The development of Caspian hydrocarbons presupposes the attraction of investments in the amount of $\$ 100-150 \mathrm{bln}$. which can be invested mainly by American companies and banks and international financial institutes of the USA. In this 
connection, one of the tasks of the USA's diplomacy is to assure favorable political conditions for protection of such investments.

The American diplomacy pays much attention to the issues of assurance of the safety of Caspian hydrocarbons supplies to the world markets. The three problems are separated. First of all, the interaction between Russia, Turkey and other countries with main investing parties aimed at settlement of conflicts in the region. Secondly, the development of regional cooperation in such direction which would allow to provide for the freedom of energy resources transit. Thirdly, use of a part of funds received from development of Caspian energy resources in order to solve socialeconomic problems of the countries in the region with the purpose of elimination of the existing sources of instability and of avoidance of occurrence of the new ones.

In this connection, the extensive activity of the American diplomacy in the Caspian region, Central Asia and Caucasus stands out, especially in respect of the problems of the Chechnya conflict. Analyzing the last actions of the USA, it is obvious that the restoration of Russia's positions in the Caucasus region is unfavorable for it in case of successful end of the antiterrorist operation in this region (Colgan, 2009).

The private sector, by which the overwhelming part of the industrial facilities and deposits are owned, plays a key role in the US's fuel and energy sector. At the same time, the American government still owns considerable reserves of energy resources on the lands which are federally owned, as well as separate energy enterprises. In regulation of FES activity, the US government mainly uses indirect methods and means peculiar to the market economy.

The Department of Energy which had developed the US National Energy Strategy plays a key role in the energy policy of the country. Individual issues of the energy policy are dealt with by the Federal Energy Regulatory Commission, the Atomic Energy Commission, the Department of Internal Affairs, the Department of Justice, the Environmental Protection Agency and the Congress of the USA, both chambers of which have special committees for energy. As internal and external aspects of the US energy policy are closely connected, discussions thereof frequently take place jointly at different levels of the legislative and the executive branches of power.

The issues of the energy policy in international relations are directly coordinated by the Department of State which closely interacts with the Departments of Energy, Trade and Finance, National Security Council, other federal departments and leading energy companies and their associations. Often, the President and the Vise-President get themselves involved in the foreign energy policy. There is a well-adjusted close interdepartmental coordination which mechanisms function on the basis of different temporary and constant working bodies. In particular, the Caspian problem is discussed within the frameworks of a constant body of interdepartmental coordination which is comprised of the representatives of the NSC, the Department of State, the Department of Energy, and of other departments. 
The responsibilities of the Department of State include development, coordination and implementation, jointly with other federal authorities, of foreign and domestic energy policy of the USA. Since the mid- $1970^{\text {th }}$, within the Department of State, a specialized division for international energy policy is functioning, which nowadays together with the subdivisions on raw material policy and economic sanctions is a part of a "bush" which is directly subordinate to a high-rank official of the Department of State at the level of deputy minister.

This Department works in tight connection with the Ministries of Energy, Trade and Finances, and with American and foreign companies and their associations (for example, American Petroleum Institute), and also with academic institutes, funds and consulting firms. Among the main tasks of this department are: coordination of all energy problems in bilateral and multilateral relations with more important countries, regions and international organizations, as well as informing and consulting of all territorial and functional subdivisions on energy problems (Walter, 2014).

There are two divisions which deal with relations with countries producing and consuming energy resources, which are part of the International Energy Policy Management Department. The competence of the Department of Consuming Countries covers the following issues: bilateral relations with member countries of OECD, coordination of the USA activity in IEA, first of all the work of constant committee of IEA on the long-term cooperation and functioning of the system of collective energy security of IEA, international aspects of internal energy policy and programs of the USA. This Department is busy with coordination of the USA policy in APR, including the working group on energy APEC and also energy problems in relations to EU (Kalicki, 2013).

The Department is busy with the ecological aspects of energy policy having the international meaning, and also the issues of international cooperation in the area of energy saving, energy effectiveness, development of new and renewable sources of energy. Moreover, the employees of the Department deal with the international economic aspects of the nuclear energy development. In particular, this Department has close ties with the State Department Administration for the Nuclear Energy and corresponding subdivision of the Department of Energy develops the general directions in respect of the nuclear energy of the former USSR.

The Department of Countries Producing Energy Resources is responsible for development and implementation of the American policy in bilateral and multilateral relations with main producing countries, primarily with those exporting oil and gas. The situation in these countries is studied attentively from the point of view of its effect on the American economic interests. The employees of the Department typically head the American delegations on the corresponding international energy forums, including those taking place under the aegis of IEA, or are members of these delegations on behalf of the Department of State (Denning and McCall, 2000). 
The issues of coordination of energy cooperation with Canada, Mexico, main oil producing countries of Central and South America, and also within the frameworks of NAFTA, are within the competence of department. The employees of the department analyze the situation on the world market of oil and gas, and develop the basic recommendations in relation to OPEC and GIPE, and also certain countries, including those which are not members of these organizations, including Azerbaijan, Kazakhstan, Turkmenistan and Uzbekistan. A separate issue is coordination of actions in relation to the execution of oil sanctions of UNO by Iraq, and also the American policy of strict measures for limitation of the action of Iran and Libya on the world energy market. The development of policy in relation to Russia, other CIS countries, and also some countries of East Europe is an important direction of the Department's work.

The development and implementation of the foreign energy policy are carried out on the basis of close interdepartmental coordination, which mechanisms were developed in the organizational and legal aspect. The different variants of concepts in the field of energy diplomacy are developed in "think tanks", such as Heritage Fund, RAND Corporation, American Petroleum Institute, etc. Typically it is made under the order of either governmental departments, including the Department of State, or of American companies. In particular, in the multicenter study of Heritage Fund issued in March in 1996 on the issues of Caspian and Central Asian countries, an attempt was made to develop recommendations for the American Government on a range of region countries, proceeding from the interests of the foreign energy policy of the country.

The Cambridge Energy Research Association (CERA), having the say-so in the world energy establishment, plays an important role in the intellectual provision of this policy. Among the distinctive features of American energy diplomacy traditionally is the pragmatism peculiar to the American nation, and displayed in the desire to achieve maximally beneficial solution of an issue from the point of view of American interests, in a minimum possible period of time. In this connection, the searches of the shortest ways of achievement of the agreements necessary for American party, simplification, sometimes excessive, of problems and aspiration to divide them into constituents, prevail in the methods of conduct of negotiations. This lead to that the representative of the USA pay a lot of attention to the technical details that sometimes impede the discussion of a problem in its essence.

\section{American energy policy prospects: New goals and strategies}

The US has serious intentions to strengthen its energy independence, and, perhaps, even dominate in this area. In this regard, the actions carried out by the United States do not look fragmented and inconsistent.

The Middle East is one of the most critically important energy regions of the world. And the US policy towards it seems very active and assertive. However, the US 
military policy varies in its manifestations, depending on the country. Saudi Arabia, being a leader in proven reserves and production of oil in the world, has chosen a path of cooperation with the United States. In the $1970^{\text {th }}$, the royal house was convinced by Washington of the need for a plan of modernization of the state, and received political and military guarantees of preservation of the regime in this country from the US. In exchange, Saudi Arabia has made a commitment to deliver oil to the United States in necessary quantities, as well as to place all contracts for the purchase of equipment with the companies from the US and to buy government bonds from the US Government. And until now, the United States supports the royal house of Saudi Arabia and supplies weapons to the country (Borovsky, 2008).

Quite different developments of events are observed in Iraq. Based on intermittently disseminated information, we cannot exclude that the US Iraqi campaign launched in March 2003 has been associated with Washington's desire to gain a foothold in the areas of oil production, taking into account the adverse prospects of ensuring the supply of this kind of fuel to the world. Iraq has the third largest oil reserves in the world and control over it was the focal point of the US energy strategy developed by Vice President Richard Cheney and his associates in the Republican Party (Klimenko, 2007). US had to admit that weapons of mass destruction, whose existence was announced as the main pretext of a military operation in Iraq is not.

According to the French newspaper Le Nouvel Economist, Washington used the anti-Taliban campaign to strengthen its presence in Central Asia because the part of it exposed to the Caspian Sea contains vast reserves of hydrocarbons. Moreover, the establishment of US control over Afghanistan will provide an opportunity to resurrect the idea of building a gas pipeline from Turkmenistan to the Indian Ocean through Afghanistan and Pakistan (Borovsky, 2008).

Relations between the US and Iran are also being developed, taking into account the energy factor. At first sight, the situation is very simple, and the primary motivation of Washington's negative perception of Iran's policy is Iran's desire to put into the service of some traditional and sometimes even militant Islamic values modern missile and nuclear technology and weapons (Borovsky, 2008).

However, not only and not just this is the main reason for this is yet irreconcilable contradictions between the US and Iran. In 1996, the United States announced the launch of sanctions against any country or company which will decide to invest in Iran's economy more than \$ 20 million. This is caused by the fact that Iran pursues (in the world energy) an independent from the United States and even potentially unfavorable to them course. Moreover, Iran, possessing the most significant military and economic potential, is able to destabilize the situation in one of the most important energy regions at any moment, which is unacceptable to the United States (Geri, 2001). 
There are quite a lot of energy purposes of the US in Iran; first of all, the US is interested in the long term in the possibility to procure significant volumes of oil and gas from Iran. As in the case of Iraq, the US is trying to deprive China of oil supplies from the largest oil-producing region. Added to this there is the reluctance to allow India with its plans to build a gas pipeline to receive gas from Iran, as well as the desire to destroy Russia's plans to build a gas OPEC - an Organization of countries with the largest gas reserves, the ability to obtain control of the world reserves of natural gas. In this context, the aggravation of relations between Iran and the US seems to be quite justified. Intermitted requirements of some politicians to prevent the emergence of nuclear-armed Iran clearly fit into the general militarypolitical line for regime change in this country and establishing control over its energy resources (Borovsky, 2008).

Quite contradictory looks the US policy toward Central Asia and the Caspian region. On the one hand, there is a visible considerable progress, and on the other, it is clear that since 2005 the US has been gradually displaced from the region by Russia and China. The US strategy towards the region includes achieving of several goals. The US and its allies should be provided with the access to vital sources of energy resources in the region, allowing them (the US) to satisfy their needs. International terrorism in the region must be knocked for a goal.

The US must also help to improve the situation in the political and social environment of the country which accumulates the spread of terrorism, including the preservation of regional stability in the "arc of instability". The US foreign policy "is to make a controlled growth of an ambitious and increasingly influential in the region, but potentially unstable China." In addition, the United States must do everything possible to "restrain the ambitions of other powers competing for dominance in the region such as Iran and India" (Borovsky, 2008).

However, the implementation of the US plans is hindered by Russia and China, for which Central Asia is one of the most important places of geopolitical efforts. On the way of Washington's aims it gradually encounters a disturbance in the face of the Shanghai cooperation organization and the organization of the Collective Security Treaty. That is why one of the main uses of military force will be the practice of "color revolutions", inspired by the US in order to establish friendly regimes for themselves, who have successfully proved themselves in Eastern Europe and the former Soviet Union. Its enough to recall the classic example of the change of political regime in Azerbaijan, when in 1993, with the active participation of British Petroleum and British intelligence service MI6 there was a coup, and in result of that President Elchibey was ousted from power, Heydar Aliyev was returned to rule the country. No less, and perhaps greater interest for the United States represent Kazakhstan, Uzbekistan and Turkmenistan. Kazakhstan has oil, and Uzbekistan and Turkmenistan are gas states (Borovsky, 2008). 
One thing is clear - the US is trying to invade the traditional zone of Russian influence that affects not only the economic interests of Russia, but also threatens its military security. The control over Central Asia could open the way to a strategic region of Russia - Urals. Moreover, neither China nor India cannot afford to that the United States consolidates itself in CAR, as this is contrary to their national interests. More to that, every year China becomes more and more actively involved in the struggle for the Central Asian region. The supplies of Kazakh oil to China are growing, and the number of opportunities to invest in the production of hydrocarbons and the construction of pipelines is increasing (Geri and McNabb, 2011).

All this cannot avoid being anxious on the part of Russia, so in such circumstances and Russia begins to formulate a new challenge for the military policy: ensuring national energy security. "National Security Strategy of the Russian Federation until 2020" was approved by Dmitry Medvedev in May 2009.

In parallel with these conflicts of interests, there is another potential conflict region - the Arctic. This is not accidental. The Arctic region is beginning to attract more and more attention from the US, Russia and parts of western countries. This is due to the unique geographical location, as well as the huge hydrocarbon reserves - about $13 \%$ of the world's undiscovered oil and $30 \%$ of the estimated global gas reserves.

Technological progress and global warming make plans for mining of minerals to be real and profitable. In addition, the Arctic has a military-strategic importance. The shortest air and sea routes between North America and Eurasia pass through its territory. All this explains the growth of military activity of near Arctic states. The militarization of the Arctic is becoming a reality: at first, NATO proclaimed that, and little later Russia did the same (Rusakova, 2009).

Norway, Denmark and Canada, along with the United States, are also actively involved in the struggle for the Arctic. As was reported by the Ottawa Citizen newspaper on March 23, the Canadian Forces have started creating a large compound specially intended for operations in the Arctic (Stepanova, 2001).

Confirmation of the existing international law for some time slowed down "the race for the Arctic", and not only for the near-Arctic countries, but also for NATO itself it is clearly necessary to act quickly and decisively, not allowing Russia to strengthen its position in the region. For the US at the moment, energy security means the involvement of a spectrum of methods of political, economic and military pressure on the country's suppliers of energy resources in order to create conditions for a smooth and a maximum available (as in the infrastructure and financial terms) supplies directly to the United States (Manevski, 2011).

In May 2001, the Bush administration published a plan of national energy policy "Reliable and affordable and environmentally sustainable energy for future of 
America." However, debates about the way the United States should wend to ensure its energy and, first of all, oil security, do not cease, but have rather erupted with renewed power. All experts agree that there are no easy and quick solutions for problems gradually accumulated over past decade. However, the proposed recipes are sometimes diametrically opposite. Is it necessary to give more freedom to market mechanisms or there is a need for more regulation? What should be given more attention: to energy conservation and energy efficiency or to the development of its own production of energy? And if the first, then to work to increase energy efficiency by means of administrative measures or to gradually increasing the cost of energy resources for population and industry. There is no full consensus on the issues and ensure oil security of foreign policy instruments (Gesen, 2012).

Although in general the program is aimed at increasing the production of energy resources in the United States, it is quite balanced in terms of minimizing the impacts on the environment. Until recently, the principle of propinquity was the support member of the adopted concept of energy security in the United States according to it, the most geographically close sources are considered the most reliable and thus awarded the most attention and most intended relationship.

For strategic and environmental reasons, the world must reduce its dependence on fossil fuels. But lower investment could slow the development of renewable energy technologies. A direct consequence of the financial crisis has been the growth of the role of the state. The Governments act as investors in energy infrastructure. The Governments are also again represented in the energy sector as active participants or as state-owned companies or as shareholders. And finally, companies call on to the States for construction of new energy infrastructure, such as storage of carbon dioxide and pipelines.

In such a way, Barack Obama, the US President, has put forward a plan that aims to achieve six major goals: reducing carbon dioxide emissions; priority, subsidization of cleaner and safer energy technologies; support for new productive technologies for the production of bio-fuels; guaranteeing the independence of the US economy from imported fuel supplies; increase of the energy efficiency of the national economy and the rise of the level of energy savings; restoration of American leadership in international programs for limiting environmental pollution; struggle with adverse climate changes. Such a plan was formulated by Barack Obama during the presidential race in a time of high fuel prices and stable economic growth. In 2008, the United States combusted 19.8 million barrels per day (Gesen, 2012).

The President said it was necessary to reduce the consumption on that volume, which is now imported from the Middle East and from Venezuela. Having set the objective to double the share of renewable energy sources in three years, he suggested to lawmakers to adopt an immediate additional bill to accelerate fundamental research and applied energy development, integrated implementation of 
relevant innovations and targeted federal grants amounting to of $\$ 15$ billion annually.

These measures are intended for stimulating the production of high-performance wind generators, semiconductor PV panels, new bio-fuels, low-waste equipment for coal-fired power plants, increased fuel efficiency of cars and trucks with compulsory requirement to produce all of components and to carry out the final assembly only within the United States to create new employment places for American citizens.

According to leading US oil and gas companies that do not support Obama's plan, the actual energy independence of the country in the near future is practically unattainable. The American economy will in any case continue to consume more fuel than it can supply from the exhausted domestic resource base, and significant fiscal costs on unprofitable renewable energy sources will not be able to pay off within the specified time frame. Nobuo Tanaka, executive director of the International Energy Agency, calls the president's plan "energy revolution" in the United States.

In the next 5 years the US will begin to produce miniature nuclear power plants which provide electricity for around 20,000 homes. Miniature nuclear reactors will be "monolithic"(they will not be able to deconstruct), they will use radioactive fuel that cannot be used to make nuclear weapons. In addition, they will be enclosed in a rugged case and buried in the ground directly at the consumer. The size of a mini reactor will be only a few meters, which will make possible their transportation by truck. The refueling of a nuclear power station will be made every 7-10 years. The safe lifetime will be 50 years. The developers of mini-nuclear power plants aim to reduce the cost of electricity up to 10 cents per 1 watt. The U.S. government laboratory engaged in the development and production of a nuclear power plant has already received 10 orders. Among the customers there are energy companies (Rosenbaum, 2014).

In the near future, according to the staff of this laboratory, some developing countries will appear in the number of customers. Of course, the development of mini-NPPs also pursues political goals. "He who owns the resources and energy that rules the world" (Manevski, 2011). Thus, the world's dependence on energy supply continues to grow, so the energy security becomes a strategic priority.

The main internal contradiction in us foreign energy policy, which have to be overcame by B. Obama, is that under favorable to themselves unipolar approach, the United States became to directly and indirectly contribute to the creation of a more "globalized" world, which objectively requires the joint action of different countries, such as coordination of macroeconomic regulation, energy security, solving the problems of "failed States" and regional protracted armed conflicts around energy resources, prevention of global epidemics and reducing emissions of carbon dioxide in the atmosphere (Manevski, 2011). 
However, instead of creating new and strengthening the existing international institutes aimed to solve these problems, many unilateral American actions for rapid achievement of their own short-term foreign policy goals in the recent few years only weakened the existing international structures.

Development of new energy base in the United States is one of the most important priorities of the state's national security. In accordance with the current legislation, the development of a strategy and implementation of national energy policy is entrusted to the President and six special federal agencies: the Department of Energy, the Department of Commerce, the Department of State, the Ministry of Agriculture, the Ministry of Internal Affairs and the Agency for Environmental Protection.

This strategy of US President Barack Obama is clearly aimed at a gradual significant change in the structure of the U.S. energy balance in the framework of the promotion of energy saving and greater use of renewable sources, however, its practical implementation can meet a significant challenge and will require a large investment of resources actually available just after the release of the country from its current financial crisis. The main priorities are given to solar energy, multy-fuel vehicles and plans for accelerated construction of new transmission lines and fuel pipelines for regional energy corridors. To double the share of renewable energy sources in the next three years, Obama has offered to subsidize the production of highly productive wind generators, semiconductor photovoltaic panels, new biofuels, new hybrid cars and trucks with increased fuel efficiency, fuel cells and batteries fast recharge (Manevski, 2011).

Obama's plan to invest in the development of alternative and nuclear energy is very promising due to the fact that if the US gets the leader in this field, the influence and power of the country will strengthen.

In conclusion it should be said that in general the development trends of energy is ambiguous, but the increasing role of alternative energy sources and innovative approach to nuclear energy allow to speak about the up-coming revolution in the energy industry of the United States.

\section{Conclusions}

In the American energy diplomacy, different sanctions are frequently used as an instrument in relation to those countries, which conduct the policy that doesn't correspond to the interests of America, or create, in the USA opinion, the threat to the generally accepted democratic principles or international security. In particular, it can be violation of the human rights, terroristic activity, participation in drug business, danger of nuclear weapon distribution, and usage of the prisoners' work, etc. In 1993-1997 in the United States of America, more than 60 laws and acts of executive authorities were adopted providing for economic sanctions with the 
purpose of achievement of foreign policy goals. The majority of these documents have energy hidden motive.

The USA seriously intends to consolidate its energy independence, and it is possible to try dominating in this area. In this connection, the actions of the USA don't look isolated and inconsistent. The Middle East is one of the most critically important energy regions of the world. The USA policy in its relation looks very active and forceful.

Except for Iran, Libya and Iraq, the circle of countries, in relation to which the sanctions were applied or which the USA threaten to apply, is quite wide: Nigeria and Indonesia, Italy and Canada, Mexico and Columbia, Russia and Turkey, Azerbaijan and Myanmar, Syria and Sudan, China and North Korea etc. In this connection, the laws of Helms-Burton and D'Amato-Kennedy deserve the biggest attention.

The law of Helms-Burton "On the freedom of Cuba and democratic solidarity" was signed by B. Clinton on the $12^{\text {th }}$ March in 1996. In particular, the law contains the position about that the USA will reduce their assistance to any country for the amount, equal to the amount provided by the country to Cuba as assistance or credits for completion of the NPP "Khuragua"construction, evidently directed against Russia.

The law of d'Amato-Kennedy about sanctions against foreign companies, which participate in financing of the oil and gas industry of Iran and Libya, was signed by B. Clinton on the $5^{\text {th }}$ August in 1996. In accordance with this law, the sanctions are imposed on the foreign companies, which invest into the oil and gas industry of Iran and Libya more than $\$ 40 \mathrm{mln}$. per year, and also supply goods to Libya as violation of resolutions 748 and 883 SS Uno (weapon, aircraft). Among the possible sanctions, the following appear in the law: such as refusal in the issue of licenses for export in the USA; ban for granting loans by American banks; ban for operations with American state securities; ban for purchase of the goods and services from the violating companies; refusal to issue American entrance visas.

In 1997-1998, the American legislators activated the campaign against the Russian "Gazprom", French "Total" and Malaysian "Petronas" due to their plans to participate in the development of the Iran gas deposit South Pars and Persian Gulf. At that, the anti-Iran provisions of d'Amato-Kennedy law were used.

Analyzing the situation in the USA which has presently formed in connection with the possible sanctions relating to foreign companies which intend to develop cooperation with Iran, it is possible to mention that oil and gas lobby of the country at the same time activates the campaign for the benefit of sanction mitigation, in order that American companies have possibility to enter into business relations with Iran. Such famous public figures take part in this campaign as the former aide of the 
USA president for national security Z. Brzezinski, B. Scowcroft, and also the former minister of defense D. Cheney, who considers that conducting the foreign policy in relation to oil production countries of Persian Gulf, the USA must first of all mean their strategic value from the point of view of supplies of oil in the USA and give support to creation of the most favourable conditions for expansion of the American companies in the region, where they are actively pressed by the competitors from other countries (Rach, 2007).

The potential possibilities for the conflict of interests, first of all, in the Caspian region and in Caucasus, Persian Gulf, in the considerable part of post-Soviet space, create the threat to stability on the world energy markets, and also to socialeconomic development of a number of regions at the beginning of XXI century and in great extent depends on ability of energy diplomacy of the USA and Russia find the balance of interests on the global and regional levels.

Thus, in the course of further long enough and heavy transition period, the inevitable structure of reorganization of national power engineering, the USA will be extensively forced to continue to use the imported oil and natural gas, and also to prolong foreign economic policy of diversification of the sources of their supply. Such new regions of intelligence and production of fuel raw material as different African countries, Caspian basin, prospective shelf zones of Far and Near East, will extensively acquire more value.

The results of the study can be used for the proper study of factors forming the stratagem of Kazakhstan future for more "profitable", from the point of view of the world policy of changing "the energy course" of the country. Thus, from the abovementioned, it is possible to prognosticate that in the nearest time the main conflicts for control over the resource zones can be spread in oil-gas deposits of this region, which political and economic life is the most stable; and where there is no isolation on the world arena, which geopolitical location is the most convenient for the export and transportation of the raw material produced. Accordingly, the Near East is this region, relating to the most perspective zone on the development and production of oil and gas that supposes the importance of control over oil-producing region.

Radical changes in the world of oil inevitably attract attention to the issue of energy security. Now it is clear to all that in the nearest future the role of oil as the basic course of energy will not decrease. The international system of energy security formed in 1970 on the basis of the International energy agency. The second stage of development began in 1991 after war in Persian Gulf. On this stage, the cooperation between consumers and producers on the basis of total interest in stability of oil market and world economy strengthened. Now we are on the third stage of development.

It is necessary to include new large consumers to the system of international security - China and India, and that requires trust and deepening the communication between 
them and traditional import countries. Also, the issue of physical security of energy infrastructure became urgent. The world of future forces us to think about new, more environmentally friendly, safer and cheaper sources of energy. All this depends on the technologies, which are developing very rapidly. However, while the oil remains "the blood of the world" and each day of our customary life depends on this greasy black liquid called oil.

\section{References:}

America's National Interests. 2006. The Commission on America's National Interest. Washington, 2-3.

Bialos, J. 1989. Oil imports and national security. University of Pennsylvania, Journal of International Business Law, 11(2), 235-300.

Borovsky, Y. 2000. The politicization of global energy. International processes 6(1), 67.

Caspian Region Energy Development Report. 2007. Washington, 4-5.

Caspian Region Energy Development Report. 2008. Washington, 2-3.

Chomsky, N. 2004. Hegemony or Survival: America's Quest for Global Dominance (American Empire Project). New York, Holt Paperbacks.

Colgan, J. 2013. Petro-Aggression: When Oil Causes War. UK, Cambridge University Press.

Comprehensive National Energy Strategy. 2008. Washington, 24-25.

Cox, M. and Stokes D. 2008. U.S. Foreign Policy. UK, Oxford University Press.

Energy Policies of IEA Countries 1998. Review. Paris, 110-111.

Freedom of Cuba and Democracy Solidarity Act of 1996 (Helms and Burton Act). 2006. Washington.

Denning, B. and McCall, J. 2000. States' Rights and Foreign Policy: Some Things Should Be Left to Washington. Foreign Affairs 79(1), 9-14.

Geri, L. 2001. Energy Policy in the U.S.: Politics, Challenges, and Prospects for Change (Public Administration and Public Policy), CRC Press.

Geri, L., McNabb, D. 2011. Energy Policy in the U.S.: Politics, Challenges, and Prospects for Change (Public Administration and Public Policy). CRC Press, Taylor \& Francis.

Gesen, R. 2012. The Issue of nuclear power international policy. Retrieved from www.trtrussian.com/2012

Graetz, M. 2013. The End of Energy: The Unmaking of America's Environment, Security, and Independence. USA, The MIT Press.

Hamilton, L. 2000. International Economic Issues and US Foreign Policy. US Foreign Agenda 5(1), 22-24.

Kalicki, J. 2013. Energy and Security: Strategies for a World in Transition. Woodrow Wilson Center Press/Johns Hopkins University Press.

Karpov, L. 1998. Federal government and stimulation of the energy saving in the USA. The USA - EPI 12, 25-66.

Klimenko, A. 2007. Energy factors in military policy of the States of Eurasia. Energy dimensions of international relations and security in East Asia. Edited by A.V. Torkunov, Moscow.

Kuranov, A. 2010. Energy strategy of the USA: aims and resources. Retrieved from http://www.rusoil.ru/2010

Manevski, E. 2011. The Problem of energy resources the struggle for world leadership. Retrieved from http://www.worldpolit.ru/2011 
Page, B. 2006. The Foreign Policy Disconnect: What Americans Want from Our Leaders but Don't Get (American Politics and Political Economy Series). USA, University of Chicago Press.

Pascual, C., Elkind, J. 2009. Energy Security: Economics, Politics, Strategies, and Implications. USA, Brookings Institution Press.

Rach, N. 2007. Facing \$100/BBL Oil. Oil \& Gas Journal, 10(5), 38-39.

Rosenbaum, W. 2014. American Energy: The Politics of 21st Century Policy. USA, CQ Press.

Rusakov, A. 2009. Arctic is arming. Retrieved from http:// www.novopol.ru/02.04.2009

Stepanova, E.A. 2002. Civil-Military relations in operations. Moscow: Human Rights. Strategic plan 2014-2018. U.S. Department of Energy. Retrieved from http://energy.gov/sites/prod/files/2014/04/f14/2014_dept_energy_strategic_plan.pdf

Stokes, D., Raphael, S. 2010. Global Energy Security and American Hegemony (Themes in Global Social Change). USA, Johns Hopkins University Press.

The national security strategy of Russian Federation up to 2020. Retrieved from www.scrf.gov.EN/2010

The Role of IEA Governments in Energy. 2002. Paris, 294-295.

Trubowitz, P. 1998. Defining the National Interest: Conflict and Change in American Foreign Policy. (American Politics and Political Economy Series). USA, University of Chicago Press.

Victor, D., Hults, D. and Thurber, M. 2014. Oil and Governance: State-Owned Enterprises and the World Energy Supply. UK, Cambridge University Press.

Yergin, D. 1991. The Prize: The Epic Quest for Oil, Money, and Power. USA, Free Press.

Zhiznin, S., Mironov, N. 2009. Formation of the energy security system APEC. TEK 1, 2930.

Zhiznin, S. 2010. Energy diplomacy. Moscow, Nauka. 